\title{
JEKK
}

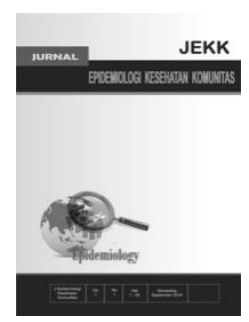

\section{Potensi Formulasi Self Microemulsifying Drug Delivery System (SMEDDS) Ekstrak Biji Kedelai (Glycine soja) Terhadap Penurunan Kolesterol pada Penyakit Jantung Koroner}

\author{
I Nengah Raka Swastika*, Ni Ketut Ristiani*, Adrian Wiryanata Gorintha*, Agung Wiwiek Indrayani** \\ "Program Studi Sarjana Kedokteran dan Profesi Dokter Fakultas Kedokteran, Universitas Udayana, \\ ${ }^{* *}$ Departemen Farmakologi dan Terapi Fakultas Kedokteran, Universitas Udayana
}

\begin{abstract}
Background: Coronary heart diseases (CHD) is a disorder that caused by blockage of coronary arteries due to the process of atherosclerosis which disrupts the blood supply to the heart muscle. According to Sample Registration System (SRS) Indonesia in 2014, CHD is a second highest cause of death after stroke that is $12,9 \%$ of all cause of death in Indonesia. Therefore, this study aims to examining the effect of soybean extract encapsulated with Self Microemulsifying Drug Delivery System (SMEDDS) on LDL levels in coronary heart model rats. Based on various study, isoflavone aglycone genistein is the main flavonoid in soybean seed that has potential as an antioxidant. To increase bioavailability of aglycone isoflavones, a SMEDDS is needed. In this regard, the purpose of this reseach is to examine the potential of soybean seed (Glycine soja) extract to reduced cholesterol in CHD.

Methods: The method used is a literature review with literature sources in the form of relevant articles from the search engines, namely Google Scholar, Pubmed, ScienceDirect, and Research Gate. Inclusion criteria included journals containing the keywords "soybean (Glycine soja)", "Coronary Heart Disease", "SMEDDS", and "genistein isoflavone aglycone".

Result: Isoflavone aglycone as an potential antioxidant that is able to bind free radicals and and also lowering LDL, Triglycerides, and glucose levels in hyperglycemic states and increasing HDL.

Conclusion : Soybean seed extract with SMEDDS encapsulation have a potential to decrease LDL level in coronary heart disease.
\end{abstract}

Keywords: Coronary heart disease; Isoflavone aglycone genistein; Lowering LDL; SMEDDS; Soybean seed

*Penulis korespondensi, agungwiwiek@unud.ac.id 


\section{Pendahuluan}

Penyakit Jantung koroner masih menjadi permasalahan yang penting di dunia kesehatan. Dimana penyakit jantung koroner (PJK) ini merupakan suatu kelainan yang diakibatkan oleh adanya penyumbatan pada arteri koronaria karena proses aterosklerosis sehingga akan mengganggu suplai darah yang kaya oksigen dan nutrisi ke otot jantung. ${ }^{1}$ PJK merupakan salah satu penyakit kardiovaskular yang sangat mematikan. Menurut Sample Registration System (SRS) Indonesia tahun 2014, PJK merupakan penyebab kematian tertinggi kedua setelah stroke yaitu sebesar 12,9\% dari seluruh penyebab kematian di Indonesia. Berdasarkan jenis kelamin, prevalensi PJK lebih tinggi pada perempuan yaitu $1,6 \%$ dan pada laki-laki yaitu $1,3 \% .^{2}$

Pemerintah sudah menerapkan beberapa langkah dalam mengatasi peningkatan risiko terjadinya PJK, salah satunya adalah Gerakan Masyarakat Hidup Sehat (GERMAS). Selain itu, sudah ada pula obat yang digunakan untuk mengatasi PJK, seperti niasin. Akan tetapi, niasin ternyata memiliki beberapa efek samping dalam penggunaanya, dimana dapat menimbulkan tekanan darah rendah jika dikonsumsi dalam jangka waktu yang panjang. ${ }^{3}$

Penanganan penyakit jantung koroner dengan memanfaatkan esktrak dari biji kedelai berpotensi menjadi salah satu solusi alternatif yang lebih murah, efektif dan mudah didapat. Di Indonesia kedelai adalah komoditas pangan utama setelah padi dan jagung. ${ }^{3}$ Kedelai merupakan salah satu tanaman golongan Leguminase yang kaya akan kandungan antioksidan terutama yaitu kandungan isoflavon. Kandungan isoflavon pada kedelai terutama isoflavone aglikon genistein merupakan senyawa yang memiliki efek kuat dalam penurunan kolesterol pada darah. ${ }^{4}$ FDA (Food and Drug Administration) telah mengakui bahwa makanan yang mengandung protein kedelai merupakan salah satu pelindung manusia dari penyakit jantung koroner. Asupan $25 \mathrm{~g}$ protein kedelai per hari diakui akan mengurangi kolesterol (3,77\%), LDL-kolesterol $(5,25 \%)$, triasilgliserol $(7,27 \%)$ dan peningkatan serum secara signifikan HDL-kolesterol $(3,03 \%) .^{5}$ Isoflavon akan menginduksi peningkatan eksresi fekal asam empedu dan steroid, kemudian memberikan respon ke hati untuk mengubah kolesterol menjadi empedu sehingga hal ini dapat menurunkan kolesterol LDL tubuh dan pada akhirnya kadar kolesterol pada darah akan mengalami penurunan. ${ }^{6}$

Senyawa bioaktif pada isoflavon yang berperan penting dalam penurunan kolesterol adalah isoflavon yang tidak terikat oleh glukosa atau sering disebut aglikon ini memiliki sifat non polar atau sifat yang sukar larut dalam air. ${ }^{5}$ Untuk meningkatkan bioavaibilitas dari isoflavon aglikon ini, maka diperlukan suatu strategi formulasi agar senyawa ini dapat larut mudah di dalam air sehingga penyebarannya dapat menyeluruh ke seluruh tubuh. Self Microemulsifying Drug Delivery System (SMEDDS) ini merupakan salah satu pendekatan yang paling menarik dalam peningkatan kelarutan, penyerapan, dan pelepasan oral untuk obat yang memiliki kelarutan yang buruk di dalam air. Sebelum dapat diadministrasikan secara oral, pembentukan SMEDDS diperlukan campuran antara minyak, surfaktan, sedikit air dan senyawa-senyawa kosurfaktan sebagai hydrophobic drug carrier. ${ }^{7}$

\section{Metode}

Metode penelitian yang digunakan adalah literature review dimana data diperoleh dari sumber literatur yang relevan dan database ilmiah berbasis online, yaitu Google Scholar, Pubmed, ScienceDirect, dan Research Gate. Literatur selanjutnya disaring menurut kriteria inklusi dan eksklusi. Kriteria inklusi meliputi jurnal yang mengandung kata kunci ("biji kedelai (Glycine soja)", "Penyakit Jantung Koroner", "SMEDDS", dan "isoflavone aglikon genistein"), baik jurnal review artikel maupun jurnal memiliki jangka waktu maksimal sepuluh tahun terakhir. Kriteria eksklusi adalah jurnal yang tidak membahas informasi kata kunci, hanya artikel protokol jurnal dan memiliki jangka waktu jurnal maksimal sepuluh tahun terakhir, kecuali tidak ada penelitian terbaru yang relevan dengan referensi penelitian ini. Setelah dilakukan studi literatur, tahap selanjutnya adalah melakukan skrining, sehingga didapatkan 24 artikel yang relevan untuk dijadikan referensi dalam literatur ini. 


\section{Hasil}

\section{Patogenesis Penyakit Jantung Koroner}

Penyakit Jantung Koroner (PJK) merupakan penyakit yang terjadi pada arteri koronaria dimana terjadi penyempitan pada arteri koronaria yang diakibatkan oleh aterosklerosis. ${ }^{8}$ Proses aterosklerosis pada arteri koronaria diawali dengan sel endotelial disfungsional yang distimulasi oleh senyawa-senyawa proinflamasi, peningkatan aktivasi Nuclear Factor Kappa $B$ (NF-kB) dan tertahannya lipoprotein seperti LDL pada daerah subendotelial. LDL yang tertahan akan dimodifikasi menjadi Oxidized LDL (Ox LDL) yang bersifat aterogenik. Hal ini akan mendorong aktivasi sel endolel, sehingga sel endotel yang teraktivasi akan mengeluarkan selsel adhesi seperti Selectin, Vascular Cell Adhesion Molecule-1 (VCAM-1) dan chemoattractants (MCP-1) yang mengakibatkan terjadinya pelekatan dan transmigrasi sel monosit ke subendotelial. Setelah itu, sel monosit akan berdiferensiasi menjadi makrofag. Makrofag selanjutnya akan melakukan fagositosis terhadap Ox LDL sehingga menjadi sel busa (foam cell). ${ }^{9}$ Sel busa lama-kelamaan akan berubah menjadi inti lipid dengan pelindung berupa fibrous cap. Penimbunan sel busa dengan fibrous cap pada arteri koronaria akan menyebabkan terjadinya penyumbatan vaskularisasi atau Penyakit Jantung Koroner (PJK). ${ }^{10}$

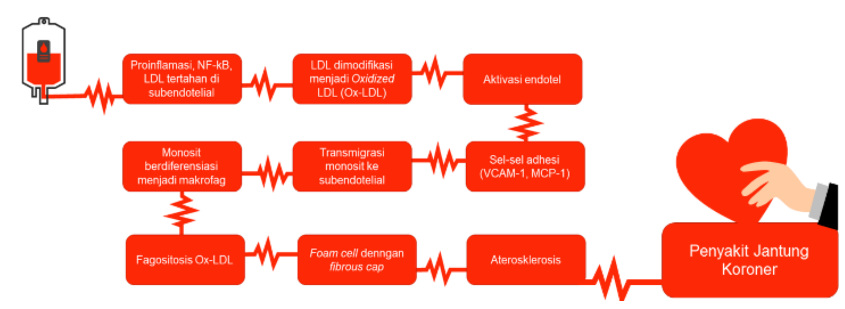

Gambar 1. Patogenesis Penyakit Jantung Koroner ${ }^{8,9}$

\section{Ekstrak Isoflavon Pada Biji Kedelai (Glycine soja)}

Senyawa isoflavon merupakan flavonoid utama dalam kandungan biji kedelai yang memiliki potensi sebagai antioksidan untuk mencegah terjadinya oksidasi lemak di dalam tubuh. Pada biji kedelai, isoflavon ini terbentuk sebagai glikon yang tidak dapat diserap dalam bentuk aslinya karena sifatnya yang hidrofilik dan memiliki berat molekul yang tinggi. ${ }^{11} \mathrm{Hal}$ inilah yang mengakibatkan wajibnya dilakukan konversi dari glikon menjadi aglikon. Diantara berbagai jenis turunan senyawa isoflavon, aktivitas antioksidan tertinggi dimiliki oleh isoflavon aglikon, lebih tepatnya adalah senyawa isoflavone aglikon genistein. ${ }^{4}$ Patogenesis penyakit jantung koroner dapat dilihat pada gambar 1 .

\section{SMEDDS}

SMEDDS merupakan suatu campuran yang jelas dari minyak, surfaktan dan kosolven atau kosurfaktan. SMEDDS dirancang untuk membentuk mikroemulsi $\mathrm{O} / \mathrm{W}$ dengan agitasi ringan yang dihasilkan oleh motilitas GIT diikuti oleh solubilisasi dan absorpsi obat. ${ }^{12}$ Formulasi SMEDDS meningkatkan kelarutan obat dan penyerapan dengan menjadikan area permukaan interfacial yang lebih luas. Komposisi dari SMEDDS terdiri dari komponen minyak, surfaktan, kosurfaktan, dan obat itu sendiri. Minyak merupakan komponen penting dari SMEDDS, sebagai solubilisasi dan akses obat yang sulit larut dalam air ke sirkulasi limfatik. Surfaktan dalam SMEDDS berperan penting dalam melarutkan cairan hidrofobik. Perilaku solubilisasi surfakan dalam obat akhirakhir ini sedang populer karena efek dari penghambatannya dalam pengendapan obat in vivo. Cosolvent berperan dalam memutuskan ikatan surfaktan dengan obat hidrofobik karena tugas selanjutnya adalah akan memasukkan air ke dalam formulasi ini. Ketika kelarutan obat yang buruk dalam air (seperti isoflavon aglikon) menjadi alasan utama dalam penyerapan obat yang tidak memadai, maka formulasi dalam bentuk lipid akan lebih disukai. ${ }^{13}$

\section{Mekanisme Konstruksi Ekstrak Biji Kedelai (Glycine soja) Terenkapsulasi SMEDDS}

Pertama-tama biji dari tanaman kedelai ini digiling dengan menggunakan penggiling tepung untuk dijadikan tepung. Setelah terbentuk tepung, kemudian tepung ini dimaserasi dengan etanol dengan perbandingan 1:5 selama 1-2 hari. Tahap selanjutnya yaitu dilakukan filtrasi dengan kertas saring. Hasil dari maserasi akan diuapkan dengan alat ekstraksi dengan metode soxhlet, sehingga akan 
didapatkan ekstrak kental. Sementara pembuatan formulasi SMEDDS dibuat dengan mencampurkan minyak dengan tween 80 dan PEG 400 sesuai dengan tabel 1, yang kemudian dilakukan optimasi dengan software SPSS 20.0 untuk medapatkan formula yang optimum. Campuran dihomogenkan dengan menggunakan vortex selama 5 menit, setelah itu dicampurkan dengan $10 \mathrm{~mL}$ formulasi SMEDDS dengan $20 \mathrm{mg}$ ekstrak isoflavone. Campuran ini kemudian diaduk dengan menggunakan magnetic stirrer dengan kecepatan $300 \mathrm{rpm}$ selama satu jam, yang dilanjutkan dengan menambahkan $100 \mathrm{~mL}$ air suling kemudian diaduk dengan magnetic stirrer pada suhu $37^{\circ} \mathrm{C}$ dengan kecepatan 300 rpm. $^{14,15}$

Tabel 1. Perbandingan Formulasi Minyak, Surfaktan, dan Kosurfaktan SMEDDS

\begin{tabular}{ccc}
\hline Minyak (mL) & $\begin{array}{c}\text { Tween 80 } \\
(\mathbf{m L})\end{array}$ & $\begin{array}{c}\text { PEG 400 } \\
(\mathbf{m L})\end{array}$ \\
\hline 2,500 & 5,625 & 1,875 \\
1,875 & 6,875 & 1,250 \\
1,250 & 6,250 & 2,500 \\
2,500 & 5,000 & 2,500 \\
1,250 & 6,875 & 1,875 \\
1,875 & 5,625 & 2.500 \\
1,250 & 7,500 & 1,250 \\
2,188 & 6,250 & 1,563 \\
1,875 & 6,250 & 1,875 \\
1,875 & 6,563 & 1,563 \\
\hline
\end{tabular}

\section{Mekanisme Administrasi dan Distribusi Ekstrak Biji Kedelai (Glycine soja) Terenkapsulasi SMEDDS}

Pengunaan metode SMEDDS untuk mendistribusikan obat dapat memberikan keuntungan lebih bila menggunakan metode distribusi oral. Selain kemudahan administrasi dan faktor kenyamanan pasien, permasalahan bioavailabilitas dan tingkat penyerapan yang sering muncul dalam pemberian obat rute oral, dapat diatasi dengan metode formulasi SMEDDS. Surfaktan yang digunakan dalam SMEDDS berpean penting untuk melarutkan cairan hidrofobik, sementara itu minyak yang dipakai dalam formulasi SMEDDS berpean penting untuk meningkatkan solubilitas dan akses obat yang sulit terlatur dalam air ke sistem sirkulasi limfatik. Karena beberapa keunggulan inilah maka rute administrasi via oral lebih diminati. ${ }^{10}$ Formulasi SMEDDS sendiri telah diketahui dapat meningkatkan bioavailabilitas obat Mefenamic acid, Osthole dan methrotrexate. ${ }^{16,17,18}$

\section{Mekanisme Kerja Ekstrak Biji Kedelai (Glycine soja) Terenkapsulasi SMEDDS}

Senyawa isoflavon merupakan flavonoid utama dalam kandungan biji kedelai yang memiliki potensi sebagai antioksidan untuk mencegah terjadinya oksidasi lemak di dalam tubuh. ${ }^{19}$ Pada biji kedelai, isoflavon ini terbentuk sebagai glikon yang tidak dapat diserap dalam bentuk aslinya karena sifatnya yang hidrofilik dan memiliki berat molekul yang tinggi. Hal inilah yang mengakibatkan wajibnya dilakukan konversi dari glikon menjadi aglikon. Diantara berbagai jenis turunan senyawa isoflavon, aktivitas antioksidan tertinggi dimiliki oleh isoflavon aglikon, lebih tepatnya adalah senyawa isoflavone aglikon genistein. $^{20,21}$ Mekanisme dari penurunan kolesterol dari kandungan biji kedelai dikarenakan isoflavon ini memiliki sifat estrogenik yang dapat menyebabkan terjadinya penurunan LDL, TG dan kenaikan HDL dan penurunan kolesterol total dalam darah akan terjadi. $^{22}$ Peningkatan kolesterol HDL yang dipromosikan oleh kedelai ini disebabkan oleh mekanisme yang membalikan transportasi kolesterol melalui pensinyalan PPAR dan Liver $X$ Receptor (LXR) dan penghambatan pensinyalan SREBP-1c. Isoflavon dianggap sebagai aktivator PPAR $\gamma$ yang mampu menghambat potent pro-inflammatory nuclear factor, NFkB. Selain sebagai penurun kolesterol dalam tubuh, peran isoflavon secara langsung juga berdampak dalam menghindari proses inflamasi, disfungsi endotel, dan stress oksidatif yang mana proses tersebut berkaitan dalam perkembangan penyakit jantung koroner. ${ }^{6}$

\section{Efek Klinis Ekstrak Biji Kedelai (Glycine soja) Terenkapsulasi SMEDDS}

Isoflavon yang terkandung dalam biji kedelai (Glycine soja) berfungsi sebagai antiosidan yang mampu mengikat radikal bebas dan mencegah reaksinya. Pemberian isoflavon dapat menurunkan kadar LDL, TG, serta 
meningkatkan HDL. Selain itu, isoflavon juga dapat menghambat kerja enzim tirosin kinase sehingga dapat menghambat perkembangan selsel kanker seperti kanker payudaya dan prostat. $^{23}$ Diantara berbagai jenis turunan senyawa isoflavon, aktivitas antioksidan tertinggi dimiliki oleh isoflavon aglikon, lebih tepatnya adalah senyawa isoflavone aglikon genistein. ${ }^{4}$ Genistein berperan dalam cell repairing, metabolisme lemak dan glukosa serta melindungi sel $\beta$-pankreas sehingga dapat mencegah diabetes mellitus, apoptosis sel berlebihan seerta penyakit jantung seperti penyakit jantung koroner. ${ }^{24}$ Kemungkinan jalur molekuler yang memodulasi isoflavon kedelai dalam adiposity dapat dilihat pada gambar 2 .

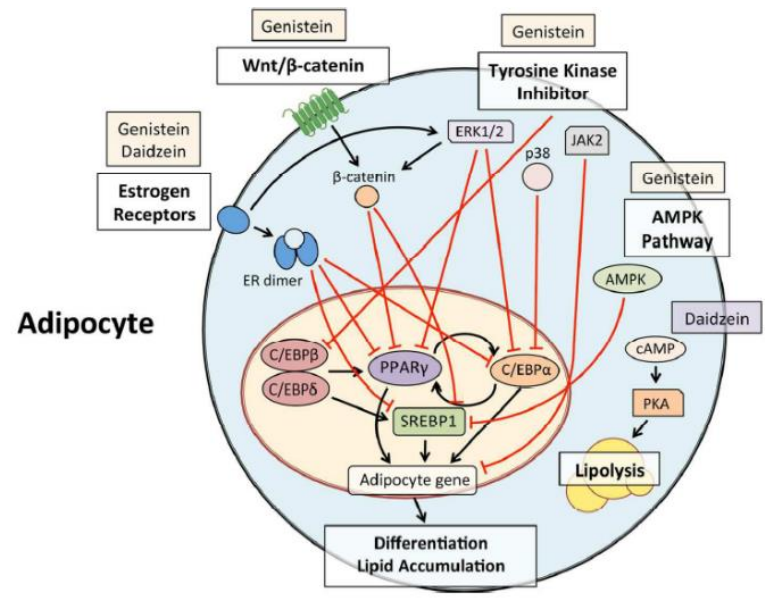

Gambar 2. Kemungkinan jalur molekuler yang memodulasi isoflavon kedelai dalam adiposity ${ }^{6}$

\section{Kesimpulan}

Adapun kesimpulan yang dapat ditarik dari pembahasan diatas ialah ekstrak biji kedelai dapat diformulasikan dalam bentuk SMEDDS dimana pengunaan metode SMEDDS untuk mendistribusikan obat dapat memberikan keuntungan lebih bila menggunakan metode distribusi oral. Isoflavone yang terkandung dalam biji kedelai bersifat esterogenik dan dapat menyebabkan penurunan LDL, TG, dan meningkatkan HDL. Mekanisme ini terjadi melalui pensinyalan PPAR dan Liver $X$ Receptor (LXR) serta penghambatan pensinyalan SREBP-1c sehingga mampu menghambat potent pro-inflamatory nuclear factor dan NFkB. Selain itu, isoflavone juga dapat secara langsung menghindari proses inflamasi, disfungsi endotel dan stress oksidatif yang berkaitan dengan penyakit jantung koroner. Isoflavone terutama genistein berperan dalam cell repairing, metabolisme lemak sehingga dapat digunakan sebagai preventif dan terapi untuk penyakit jantung seperti penyakit jantung koroner.

\section{Ucapan Terima Kasih}

Terima kasih kami sampaikan kepada seluruh tin dan Fakultas Kedokteran Universitas Udayana atas kesempatan mengikuti PKMDikti 2020.

\section{Daftar Pustaka}

1. Marleni L, Alhabib A. 2017. Faktor Risiko Penyakit Jantung Koroner di RSI SITI Khadijah Palembang. Jurnal Kesehatan. 8(3):478.

2. P2PTM Kemenkes RI. 2021. Hari Jantung Sedunia (HJS) Tahun 2019 : Jantung Sehat, SDM Unggul - Direktorat. [Internet]. [cited 7 August 2021]. Available from: http://p2ptm.kemkes.go.id/kegiatanp2ptm/pusat-/hari-jantung-sedunia-hjstahun-2019-jantung-sehat-sdm-unggul

3. Pusdatin Kemenkes RI. Situasi Kesehatan Jantung. [Internet]. [cited 7 August 2021]. Available from: https://www.kemkes.go.id/download.php?f ile=download/pusdatin/infodatin/infodatinjantung.pdf

4. Wang $X$, Liu S, Yin $X$, Bellaloui $N$, McClure M, Mengistu A. 2019. Soybean seed isoflavones respond differentially to phosphorus applications in low and high phosphorus soils. Nutrient Cycling in Agroecosystems. 113(3):217-230.

5. Swart A, Johannes I, Sathyapalan T, Atkin S. 2019. The Effect of Soy Isoflavones on Steroid Metabolism. Frontiers in Endocrinology. 10:229 
6. de Piano A, Masquio D, Dâmaso A. 2019. The Effects of Soy Products and Isoflavones in Metabolic Syndrome and Nonalcoholic Fatty Liver Disease. Bioactive Food as Dietary Interventions for Diabetes. 121-136.

7. Zhang H, Wang Q, Sun C, Zhu Y, Yang Q, Wei Q et al. 2019. Enhanced Oral Bioavailability, Anti-Tumor Activity and Hepatoprotective Effect of 6-Shogaol Loaded in a Type of Novel Micelles of Polyethylene Glycol and Linoleic Acid Conjugate. Pharmaceutics. 11(3):107.

8. Wang H, Liu Z, Shao J, Jiang M, Lu X, Lin L, et al. 2020. Pathogenesis of premature coronary artery disease: Focus on risk factors and genetic variants. Genes \& Diseases. 15-32.

9. Linton MRF, Yancey PG, Davies SS, et al. The Role of Lipids and Lipoproteins in Atherosclerosis. [Updated 2019 Jan 3]. In: Feingold KR, Anawalt B, Boyce A, et al., editors. Endotext [Internet]. South Dartmouth (MA): MDText.com, Inc.; 2000-. Available from: https://www.ncbi.nlm.nih.gov/books/NBK 343489/

10. Sianturi E, Kurniawaty E. 2019. Pengaruh Pektin terhadap Penurunan Risiko Penyakit Jantung Koroner The Effect of Pectin on Reducing the Risk of Coronary Heart Disease. Majority. 8(1):162-167.

11. Cao Y, Xing H, Yang Q, Bao Z, Su B, Yang $Y$, et al. 2012. Separation of soybean isoflavone aglycone homologues by ionic liquid-based extraction. Journal of Agricultural Food Chemistry. 60(13):3432-40.

12. Dokania S, Joshi AK. 2015. Selfmicroemulsifying drug delivery system (SMEDDS)-challenges and road ahead. Drug Delivery. 22(6):675-90.

13. Akula S, Gurram AK, Devireddy SR. 2014. Self-Microemulsifying Drug Delivery
Systems: An Attractive Strategy for Enhanced Therapeutic Profile. International Scholarly Resarch Notices. 2014:1-11.

14. Wiwiek IA, Martodihardjo S,. S,. J, Ngurah Budiana IGM,. M. 2017. Preparation and In-Vitro characterization of Self-Nano emulsifying system of C- Phenylcalix-[4]Resorcinaryl

Octacinnamate and C-Methylcalix-[4]Resorcinaryl Octabenzoate as ultraviolet absorbers. Bali Medical Journal. 2017;6(3):569-577.

15. Mandić J, Pirnat V, Luštrik M, German Ilić I, Vrečer F, Gašperlin M, et al. 2020. Solidification of SMEDDS by fluid bed granulation and manufacturing of fast drug release tablets. Internarional Journal of Pharmaceutics. 583:8

16. Kumar M, Singh D, Bedi N. 2019. Mefenamic acid-loaded solid SMEDDS: An innovative aspect for dose reduction and improved pharmacodynamic profile. Therapeutic Delivery. 10(1):21-36.

17. Sun C, Gui Y, Hu R, Chen J, Wang B, Guo $Y$, et al. 2018. Preparation and Pharmacokinetics Evaluation of Solid SelfMicroemulsifying Drug Delivery System (S-SMEDDS) of Osthole. AAPS PharmSciTech. 19(5):2301-2310.

18. Kim DS, Cho JH, Park JH, Kim JS, Song ES, Kwon J, et al. 2019. Selfmicroemulsifying drug delivery system (SMEDDS) for improved oral delivery and photostability of methotrexate. International Journal of Nanomedicine. 14:4949-4960.

19. Yoon, G., \& Park, S. 2014. Antioxidant action of soy isoflavones on oxidative stress and antioxidant enzyme activities in exercised rats. Nutrition Research and Practice. 8(6):618-624.

20. Suarsana IN, Widyastuti S, Priosoeryanto BP. 2012. Ketersediaan hayati isoflavon 
dalam plasma dan pengaruhnya terhadap nilai biokimia darah pada tikus hiperglikemia. Jurnal Veteriner. 13(1):8691.

21. Fawwaz M, Natalisnawati A, dan Baits M. Kadar isoflavon aglikon pada ekstrak susu kedelai dan tempe. Jurnal Teknologi dan Manajemen Agroindustri. 6(3): 152-158.

22. Setyawan, F. 2017. Kajian Tentang efek pemberian nutrisi kedelai (glicine max) terhadap penurunan kadar kolesterol totalpada menopause. Jurnal Pendidik Fakultas Kedokteran Universitas Muhammadiyah Malang. 1(4): 33-50.

23. Ambrosio $\mathrm{R}$, Ombra $\mathrm{MN}$, Gridelli $\mathrm{C}$, Picariello G, Di Stasio M, Volpe MG. 2016. Isoflavone Extracts Enhance the Effect of Epidermal Growth Factor Receptor Inhibitors in NSCLC Cell Lines. Anticancer Research. 36(11):5827-34.

24. Yulifianti, R., Muzaiyanah, S., \& Utomo, J.S. 2018. Kedelai sebagai bahan pangan kaya isoflavon. Buletin Palawijaya. 16(2):84-93. 